\title{
Memórias de uma atriz do Oficina
}

\author{
Memories of an Oficina's actress
}

\section{Camila Mota}

Camila Mota

Atriz, dramaturga, diretora, produtora, compositora e artista visual. Trabalha na Cia Teat(r)o Oficina desde 1997.

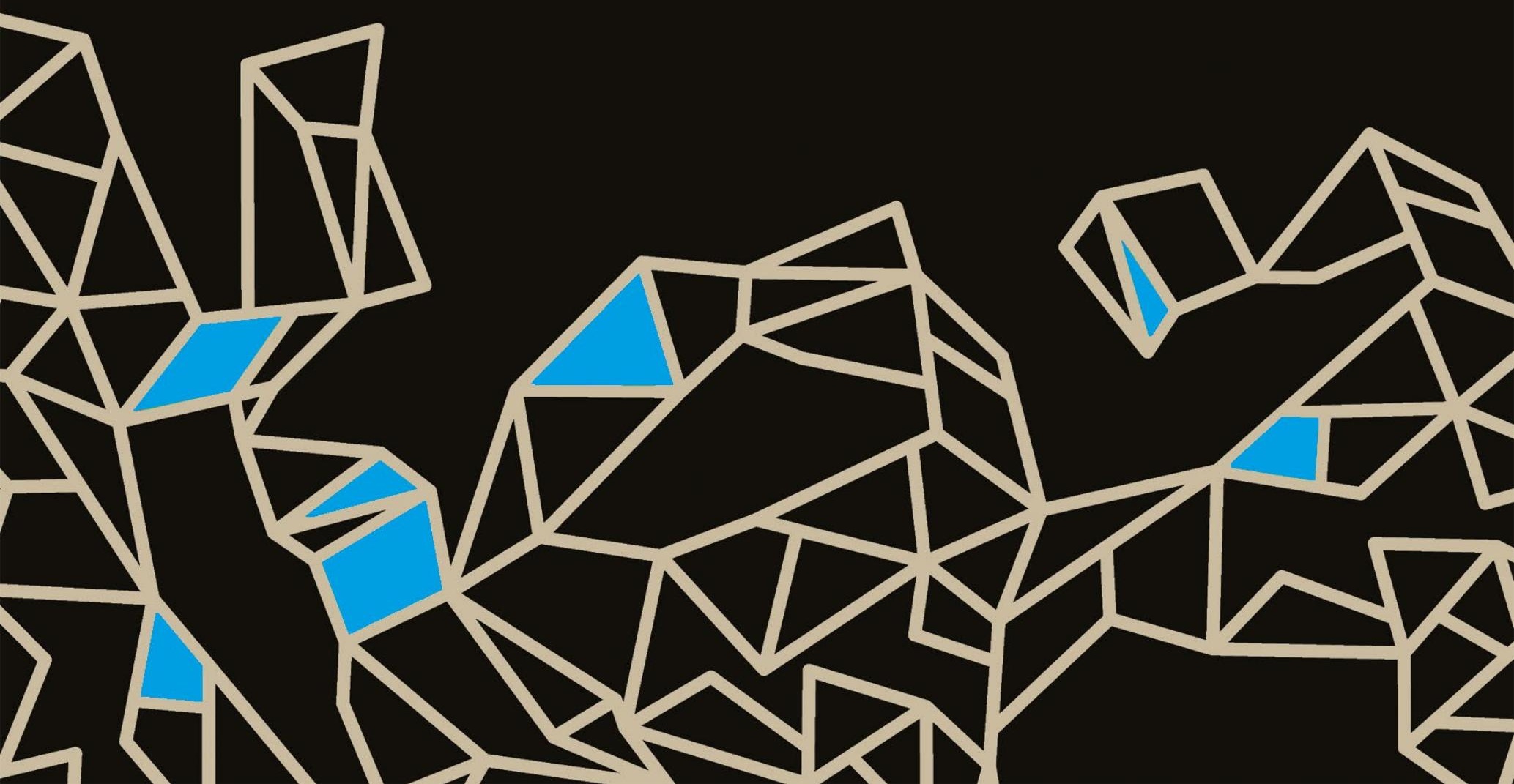


7 de junho de 1988 - teatro joão caetano no rio de janeiro, entrega do prêmio mambembe 1987 - 14 anos de idade e a emoção de estar presente nesta cerimônia.

no final, um cara sobe no palco pra receber uma homenagem e grita:

- acendam todas as luzes! luz para lu(i)z! acendam todas as luzes! luz para luís!!!

era zé celso, com a emoção quente, fervendo, pelo brutal assassinato de seu irmão, luís antônio martinez corrêa. essa cena, e marlene cantando “geni”, foram as que ficaram grudadas na memória. foi teatro. vivo. ao vivo.

minhas primeiras experiências com o teat(r)o oficina foram no papel de público.

me apaixonei pela cia assistindo a ham-let no parque lage no rio, em agosto de 1994.

vi umas três vezes e totemizo até hoje aquela casa maravilhosa na floresta, possuída por energia, tesão e science...

em dezembro de 1995, passei uma semana no candomblé, e conheci vera barreto leite - muitos trabalhos na preparação da festa de santo nós fizemos juntas.

a companhia voltou ao rio em 1996, com bacantes, e a bacante vera me chamou pra ir a são paulo.

fui e comecei a trabalhar ainda morando no rio, inventando ideias mirabolantes,

querendo montar bacantes em um porta aviões da marinha...

mas ainda bem inexperiente e incapaz de produzir essas obras.

liguei e pedi asilo teatral ao zé, que me disse pra ligar pra marcelo drummond, começavam um trabalho novo.

marcelo disse:

- chega aí e vamos ver o que é que rola... 
eu, jovem atriz, eletrificada pela energia produzida por aquela uzyna uzona, finalmente percebia o deslimite entre arte e vida e, em junho de 1997, partia pra são paulo disposta a encarar a transformação radical me entregando ao desconhecido.

estreei num vexame histórico da cia, o rala o grelo - programa de auditório comandado pelo chacrinha marcelo drummond, encerramento do sesc babel, um evento acontecido nos restos de um posto de gasolina q foi abaixo para dar lugar ao sesc pinheiros. música, teatro, artes visuais, diversidade sexual, transgêneres - uma babel de 15 dias.

o rala o grelo deveria conter tudo isso numa sucessão de números musicais, teatrais, muito improviso, comandado por marcelo.

e foi o q aconteceu. uma excepcional experiência de descontrole q começou com cinco mil pessoas assistindo e, cinco horas depois, terminava com 30.

o cordão dourado da uzyna uzona, q em 1993, corifeado pelo príncipe ham-let reabriu o teatro oficina, o terreiro eletrônico projetado por lina bo bardi e edson elito, logo após essa experiência, saía da companhia.

não era um rompimento litigioso, mas se desligavam do trabalho diário de teatro.

e teatro acontece assim, no dia a dia.

então, essa jovem atriz, 15 dias depois de sua chegada, encontrava uma terra devastada, participando de difíceis reuniões q marcam fins de paixão.

era um tanto assustador, e mesmo disposta ao desconhecido, nunca imaginei q o primeiro movimento q encontraria era um êxodo.

fiquei.

nessa época, lenise pinheiro, sempre presente naquele inverno, me alimentava com sopa e alegria. muito sabida, ela reconhecia a importância dos cabaços.

jovens atores e atrizes doidos sem técnica são fundamentais no ciclo da arte do teatro de companhias: alimentam as uzynas com seus desejos e são vorazes na fome do conhecimento da arte. 
fui a criancinha daquele momento e fiz minha cabeça no teatro, como uma iniciação no candomblé, raspando minha cabeça em cena nos espetáculos de pra dar um fim no juízo de deus em recife, no teatro apolo.

a seca me fortaleceu e hoje compreendo a riqueza desses momentos de morte coletiva, q possibilitam as viradas estéticas.

no fim de 1997 montamos, pra comemoração dos 10 anos da ethernidade de luís antonio martinez Corrêa, taniko, o rito do vale, um nô japonês última peça realizada por luís.

ali se formou um jovem coro cordão dourado - eu já não era a única criança. éramos tão cabaços e, ao mesmo tempo, tão delicados.

o coro de taniko virou o coro de cacilda! um coro muito jovem, cabaço mesmo,

que contracenava com a Beth Coelho, uma maravilhosa atriz mais experiente. e isso era a própria matéria da peça, principalmente do segundo ato, que era baseado em a gaivota, de tchekhov. zé celso queria que cacilda becker tivesse

feito arcadina em uma montagem no oficina, mas ela fez esperando godot, de

beckett, e acabou morrendo. cacilda vem da tradição maravilhosa do teatro

brasileiro de comédia, o TBC, e das companhias derivadas de lá formadas por grandes atores daquela geração, mas que foram balançadas pelo surgimento de grupos como oficina e arena, que propunham trabalhar de outra maneira.

em uma das cenas de cacilda!!!!!!, que não chegou a ser montada ainda, ela e walmor dizem que os atores desses grupos não sabiam andar direito no palco, nem usar um figurino, mas que o teatro deles vivia lotado, enquanto o deles não.

por isso, o segundo ato de cacilda! traz no cerne essa relação de cacilda, como arcadina, com o teatro de grupo que surgia naquele momento. e o conflito real entre o coro jovem e uma atriz mais experiente era muito rico e zé o incentivava, porque era justamente disso que se tratava a peça.

o coro de cacilda! virou a protagonização de boca de ouro os protagonistas de boca de ouro encararam os sertões 
e aí, no meio da multidão, já não sabíamos mais quem éramos. aquela célula era só uma informação preciosa, um código de dna em meio a tantos. nos perdemos, apodrecemos, fomos malhados na bigorna. canudos foi uma terra ocupada por uma multidão heterogênea, com objetivo comum de cultivo. isso era pressuposto antropofágico da cidade,

a terra exigia muita gente no cultivo produtivo, então juntava puta com beata com vaqueiro com ladrão... a beata continuava beata se quisesse, a puta também - aniquilação de diferenças não fazia parte do plano diretor de canudos.

pra encenar o livro, a companhia precisava encarar essa mistura.

e realmente aconteceu uma coisa milagrosa, inventamos uma economia pra trabalhar com 90 pessoas. subvertemos completamente o discurso do teatro viável economicamente, que só permite monólogos, ou peças pequenas, com cenário de cadeiras. economia escraviza a estética.

trabalhar com 90 pessoas, crianças do bairro, reinterpretando nossa vida a partir do livro de euclides da cunha, não foi uma atitude social, foi, antes de tudo, uma atitude estética.

a confluência de misturas acontece no trabalho de ensaio, corpo a corpa.

em 2010, com as dionisíacas, descobrimos o luxo de fazer as oficinas uzynas uzonas em cada cidade. eram ensaios com alguns objetivos, e um deles era reinterpretar sempre e sempre as peças, e a cultura de cada porto nos

libertou mais e mais pra interpretar tudo de novo. também demos um salto de qualidade nos ensaios. pois eram ensaios com público e isso muda tudo, atiça nosso duplo, derrete o superego. somos uma companhia de repertório, e um trabalho não consegue ter uma longevidade tão grande como a nossa, se não existe transmissão de tecnologia, produção de conhecimento, troca.

as viagens das dionis íacas nos revelaram isso, percebemos com clareza a necessidade da universidade antropófaga - existir transmitindo e recebendo conhecimento. é um detalhe fundamental na maneira de trabalhar, de ensaiar, de receber novas pessoas... e principalmente de lidar com a contribuição milionária de todos os erros. 
esses processos intenssíssimos produziram novos êxodos: o fim dos sertões; a renovação da companhia pós dionisíacas... o fim dos quatro férteis anos da primeira dentição da universidade antropófaga depois da odisseia cacilda!!!!!!!!!, em 2013 e 2014, e o êxodo forçado da pandemia, que deixa o teat(r)o oficina fechado desde março de $2020 \ldots$

vivi cacilda becker nas montagens da odisseia, dividindo-multiplicando a personagem com sylvia prado, também parte da célula-tronco coro de cacilda! em 1998. e talvez por encarnar uma entidade muito ligada à morte, q transita entre céus, terras e infernos, uma perséfone - passei a desejar os abismos desconhecidos q nos trazem os êxodos - a possibilidade de nova mudança estética.

saquei como nunca, um texto q eu mesma dizia em cacilda! em 1999, fazendo o papel de silvinha nina jovem atriz:

- nasço e morro há muitos comas

tenho sempre a frescura da recém-morrida

essa elasticidade da transição entre a vida e a morte é um ponto nevrálgico na criação de coros. a entrada ou saída de uma única pessoa transforma radicalmente o coro. pra nós, uma companhia de repertório, em que espetáculos são recriados, esse conhecimento não pode ser desprezado.

era inevitável a transformação sofrida pelo coro de bacantes nos últimos 25 anos, e essa diferença pode ser percebida nas gravações da peça de 2001 e de 2016 presentes no canal do youtube do teatro oficina. é a mesma linha, muitas vezes o mesmo desenho de cena, mas a interpretação completamente diferente, atuada por pessoas ligadas no tempo presente, fazem muita diferença.

nesse momento pandêmico, o isolamento social atinge diretamente a linguagem da companhia. conseguimos sobreviver à imposição econômica da era dos monólogos, mas ainda não conseguimos vislumbrar um futuro presente próximo pra existência em coro, que é, por princípio, aglomerada. 
antes da pandemia estourar, estávamos em cartaz com roda viva, o espetáculo que trouxe pra tropicália o coro grego. mutação de apoteose, espetáculo que dirigi na FLIP, e era uma pororoca de coros diversos, entraria em cartaz.

essas peças não conseguem nem se aventurar nos OAVNIS - objetos audiovisuais não identificados das transmissões por zoom.

talvez, depois da pletora de alegria de uma vacinação em larguíssima escala, os coros retornem e, com eles, o prazer inigualável de se dissolver na multidão.

camila mota babel bacante joana d'arc yamabushi nina celeste timóteo sineiro cabo stanislavski rainha mabe diadorim pagu cacilda becker deusolinda joão-dos-divãs juliana arquivo mangue, janeiro de 2021, antropofagiando o tempo presente e alguns escritos de outras eras.

Autora convidada 
